\title{
MAMMALS
}

\section{COMPARING SOUTH AFRICAN AND CANADIAN PRACTICES FOR MANAGING LARGE HERBIVORES IN FENCED PROTECTED AREAS}

KIVA OLSON, ${ }^{1}$ GLEN T. HVENEGAARD ${ }^{1,2}$

${ }^{1}$ University of Alberta - Augustana Campus, 4901-46 Avenue, Camrose, AB T4V 2R3 Canada

Email: glen.hvenegaard@ualberta.ca

As human civilization expands and depletes resources, protected areas, such as national parks, have become key areas of conservation. Increasingly, protected areas are becoming 'islands' of wilderness. ${ }^{1,2,3}$ As a result, wildlife cannot move freely throughout their ranges, concentrating their impacts. ${ }^{20}$ Large herbivores greatly impact vegetation in areas they occupy; ${ }^{1,3,4,5,6}$ such impacts are compounded in fenced protected areas, ${ }^{1}$ especially if predation is reduced or absent and if populations become hyperabundant. ${ }^{7}$ Therefore, wildlife managers must take a more active role. Kruger National Park (KNP) in South Africa and Elk Island National Park (EINP) in Canada are both fenced parks with large numbers of the largest herbivore species on their respective continents. KNP has the African elephant Loxodonta africana, listed as vulnerable, ${ }^{8}$ while EINP has the bison Bison bison. EINP has two subspecies of bison, wood bison $B$. $b$. athabascae and plains bison $B$. $b$. bison, ${ }^{9}$ both of which have threatened status in Canada. ${ }^{10}$ When too large or too small, the populations of these species could negatively impact overall biodiversity as it connects to ecosystem health and sustainability. There is limited literature on the management of highly abundant large herbivores in fenced protected areas on sites beyond Africa, and on comparisons between practices in Africa and North America. KNP and EINP offer an opportunity for comparison because of their similar management objectives, fencing policies, and issues with high profile populations of large herbivores that have large impacts on ecosystems. Although the parks are unique in some respects (i.e., different ecosystems, continents, and amounts of visitation), the fundamental aspects of wildlife management for large herbivores can be applied to other parks and countries. The purpose of this article is to compare past and present management strategies in KNP and EINP and the methods they employ with a goal of generating insights for improved management strategies.

\section{Study Areas}

KNP and EINP share common goals and histories (Table 1) and have some of the highest ungulate densities in the world. ${ }^{11,12}$ Elephants and bison 

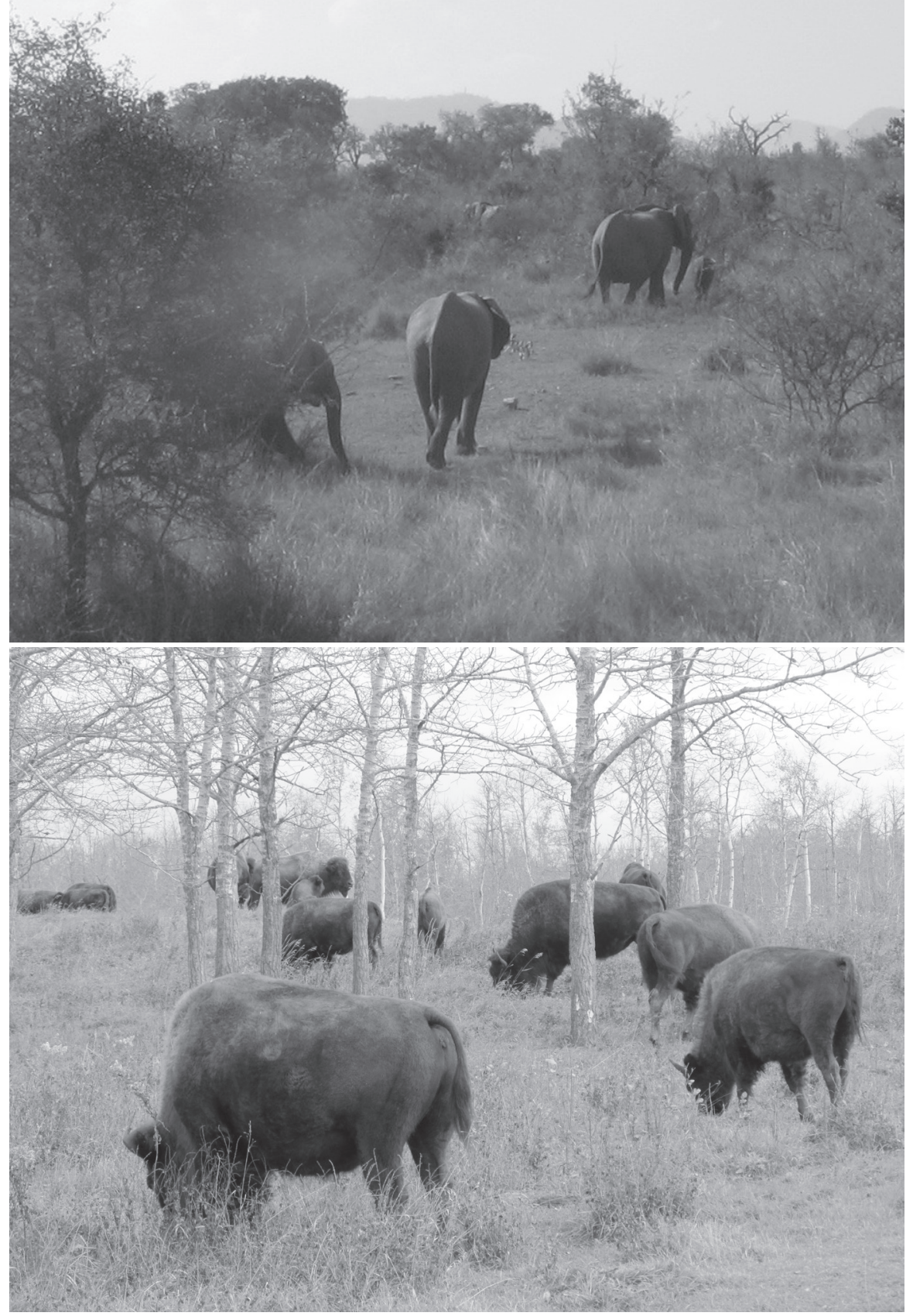

Top: A cow/calf herd of African elephants foraging in Kruger National Park. Bottom: Plains bison herd grazing in Elk Island National Park

-Kiva Olson 
share some similar characteristics in regard to their impacts on ecosystems and they are both keystone species (Table 2). Nevertheless, the parks have different sizes and densities of their largest herbivores (Table 1). We recognize that it is difficult to select two parks with enough similar characteristics to allow for fair comparisons of their management strategies; we chose these parks because they are home to their continent's largest herbivores, the parks are fenced, and we have some familiarity with them.

Depending on definitions used, these two species might be overabundant in their respective parks. Following Parks Canada's policy, a hyperabundant wildlife population meets one of the following conditions: 1) exceeds the upper range of natural variability and impacts ecological integrity, 2) has resulted from alteration of natural mechanisms for population regulation, 3 ) there is a risk of negatively affecting native species at risk, and 4) the population has caused impacts beyond the historical range of variation. ${ }^{14} \mathrm{By}$ this definition, bison in EINP are hyperabundant. Parks Canada is required to manage hyperabundant populations to maintain or restore ecological integrity. Methods to manage hyperabundant populations should best contribute to restoring or maintaining ecological integrity, mimic natural processes, and have been found to be effective on similar species. KNP also adheres to these standards and, though the term hyperabundant is not used in South African legislation, their National Norms and Standards for the Management of Elephants in South Africa ${ }^{15}$ does outline the impacts elephants can have and what measures can be taken when management plan objectives are not met due to population size or distribution. KNP's elephant population is recorded to have impacts on vegetation and, therefore, other species $^{12}$ thereby hindering KNP's biodiversity management objective. ${ }^{16}$ Therefore, given the impacts of the elephant population in KNP coupled with Parks Canada's definition and the information from the Norms and Standards ${ }^{15}$, both populations can be defined as hyperabundant.

The main methods employed to deal with abundant populations of large herbivores are translocation, contraception, culling, and nonmanagement. ${ }^{1,3,13}$ Another less common method is distribution control. Non-management is not an option for elephants in KNP because their population is too large and is not an option for EINP because of its small land area and lack of predators. The remaining methods will be discussed in relation to the management of elephants in KNP and bison in EINP and how they are employed from different strategic points of view (i.e. impact control for KNP versus numbers control for EINP). When developing and implementing a wildlife management plan, park managers need to consider the advantages and disadvantages of each of these methods, as well as the behaviour of the species on which they are being applied. 
Table 1. General characteristics of Kruger National Park, South Africa and Elk Island National Parks, Canada. 11,12,16,20

\begin{tabular}{|c|c|c|}
\hline & Kruger & Elk Island \\
\hline Established & $\begin{array}{l}1899 \text { - Sabie Game } \\
\text { Reserve } \\
1926 \text { - national park }\end{array}$ & $\begin{array}{l}1906 \text { - wildlife sanctuary } \\
1913 \text { - national park }\end{array}$ \\
\hline $\begin{array}{l}\text { Largest Herbivore } \\
\text { Present }\end{array}$ & $\begin{array}{l}\text { African elephant } \\
\text { Loxodonta africana }\end{array}$ & $\begin{array}{l}\text { Bison } \\
\text { Bison bison }\end{array}$ \\
\hline $\begin{array}{l}\text { Year Boundary } \\
\text { Fence Completed }\end{array}$ & 1975 & 1906 \\
\hline Size & $20000 \mathrm{~km}^{2}$ & $194 \mathrm{~km}^{2}$ \\
\hline $\begin{array}{l}\text { Population Size of } \\
\text { Largest Herbivore }\end{array}$ & $\begin{array}{l}\text { 2007: } 13000 \\
\text { 2012: } \sim 16700 \\
\text { Goal: } 6000-8000^{a}\end{array}$ & $\begin{array}{l}\text { 2007: } 600 \\
\text { 2011: } \sim 1065 \\
\text { Goal: } 420^{b} \\
\end{array}$ \\
\hline Density & $0.65 / \mathrm{km}^{2}$ & $3.09 / \mathrm{km}^{2}$ \\
\hline $\begin{array}{l}\text { Management } \\
\text { Objective }\end{array}$ & maintain biodiversity & maintain biodiversity \\
\hline $\begin{array}{l}\text { Fire Management } \\
\text { Plan }\end{array}$ & yes & yes \\
\hline $\begin{array}{l}\text { Water } \\
\text { Management Plan }\end{array}$ & yes & no \\
\hline
\end{tabular}

aTarget population size during culls from 1967-1994. No exact population goal since 1994. Population goal given to provide context.

${ }^{\mathrm{b}} \mathrm{Goal}$ proposed in 2009.

Analysis of Management Methods

First, translocation is a nonlethal method of removing part of a population from a protected area while maintaining the species' genetic pool and re-establishing or increasing population numbers in a new area. Translocation can be difficult because it is expensive, requires a large and skilled team, is time-consuming, and can be difficult to find suitable and accessible translocation sites. ${ }^{13,17}$ Elephants and bison are both large animals that require special handling and equipment to ensure the safety of animals and humans. Unlike bison, 

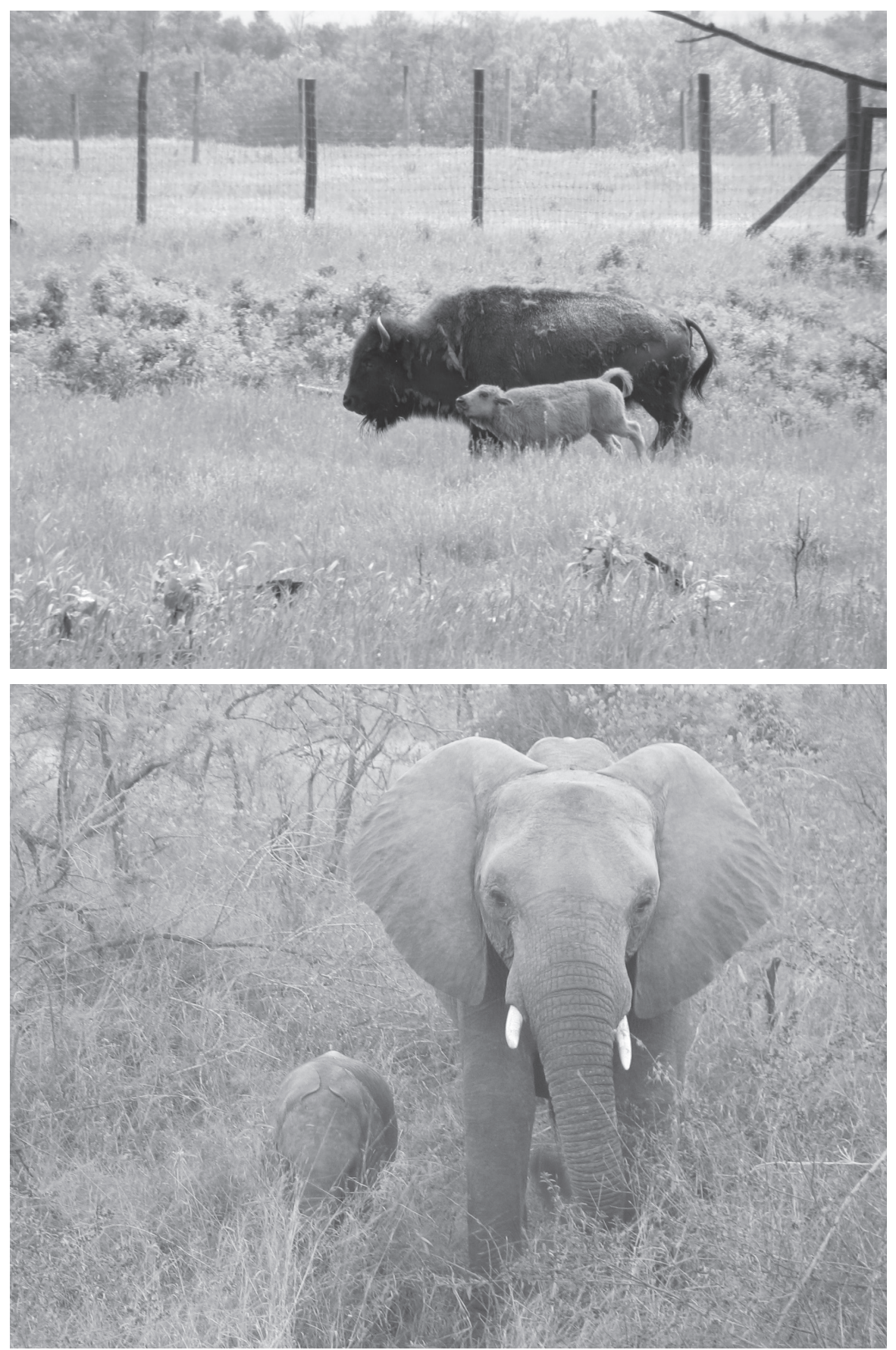

Top: A mother and calf bison move past a fence line in Elk Island National Park. Bottom: An African elephant mother with a very young calf. -Kiva Olson

71 (2) June 2013 
entire family units of elephants must be moved because of their strong family bonds. ${ }^{3,18}$ KNP started translocating elephants in 1978, mainly orphaned juveniles. ${ }^{12,17}$ This process led to the development of delinquent juveniles (ie. without the mentoring of adults) until translocations involving entire cow/calf herds and adult males was possible.

Translocation operations occur in cooler weather (Table 2), the animals are kept standing during transport, and arrive at new site in the daylight to reduce stress and injury. ${ }^{17,18,19}$ Currently, there are few translocation areas available in Africa for elephants, because most areas have populations already, are not accessible, or are in politically unstable countries. However, KNP has effectively increased its size by opening up its fenced borders to neighboring game reserves, which then become contract national parks, and to the Mozambique's Limpopo
National Park to form the Great Limpopo Transfrontier Park and Conservation Area. ${ }^{16}$ Consistent management will require considerable inter-jurisdictional cooperation. EINP is a major source herd for bison re-introduction programs in North America and Europe because of the genetic purity and disease free status of the bison. ${ }^{20}$

Second, contraception involves preventing the union of sperm and egg during sexual activity. The advantages are that no animals are killed, and it can be non-invasive and reversible. ${ }^{3,21}$ The disadvantages are the high expense, need to locate animals for follow-up treatments, time delay on population decline for long-lived species, changes to the demographic age proportions, and possible behavioural changes. ${ }^{3,21}$ There are three main types of contraception, ${ }^{21}$ the first of which is hormone control. This method can cause female elephants to enter false

Table 2. Comparison of main characteristics of the African elephant Loxodonta africana and bison Bison bison important for management of these species. . $^{4,5,17,19,35,36}$

\begin{tabular}{|l|l|l|}
\cline { 2 - 3 } \multicolumn{1}{l|}{} & Elephants & Bison \\
\hline Herd Membership & $\begin{array}{l}\text { family } \\
\text { led by matriarch }\end{array}$ & $\begin{array}{l}\text { flexible } \\
\text { led by older cow }\end{array}$ \\
\hline Lerd Size & $9-12$ individuals & $9-12$ individuals \\
\hline Migration & up to 60 years & up to 15 years \\
\hline Feeding Strategy & when range available & when range available \\
\hline Vegetation Impact & mixed grazing and browsing & grazing \\
\hline Main Predator & humans wooded areas & open up wooded areas \\
\hline $\begin{array}{l}\text { Best Time to Handle } \\
\text { and Transport }\end{array}$ & dry season (cooler weather) & winter (cooler weather) \\
\hline
\end{tabular}


estrus resulting in males harassing them and separating them from their calves. ${ }^{2,}{ }^{3}$ A KNP assessment of this method was cut short due to calf deaths. ${ }^{12}$ Second, sterilization is difficult due to the size of elephants. Laparoscopic vasectomy surgeries on dominant males is the best option as it can be performed in the bush and preserves mating competition by maintaining sex drive. ${ }^{22}$ Third, immunocontraception can be delivered remotely, causes no behavioural changes, and is reversible with time..$^{21}$ There are two types: porcine zona pellucid (pZP) and anti-gonadotropin-releasing hormone (anit-GnRH). The former produces an immune response causing antibodies to form around maturing follicles, whereas the latter hinders the release of follicle-stimulating hormones and leutinizing hormones resulting in interference with progesterone and testosterone production. ${ }^{23}$ The anti$\mathrm{GnRH}$ vaccine does impact hormone driven behaviour which would affect the social dynamics in elephant populations. ${ }^{24}$ The pZP vaccine has been used effectively on elephants and holds the most promise; anti$\mathrm{GnRH}$ has not been fully tested. KNP had the first field testing of pZP on elephants in 1996 and it was effective, ${ }^{24,25}$ but the long-term effects on herd dynamics are unknown. 3,12,26 Contraception is not a viable option on a large scale for KNP's elephants due to population size. The use of contraceptives for population control in bison is relatively new, and there is little research on its effectiveness. Any work done has dealt with deterring disease transfer.
While contraception has not been used in EINP, it has been used for wild horses (Equus ferus) and whitetailed deer (Odocoileus virginianus) in North America. ${ }^{27}$

Third, culling is an effective but controversial method. It quickly reduces large populations, effectively controls disease, and can result in revenue from product sales. ${ }^{1,3,13}$ However, culling causes a loss to the genetic pool, appears counterproductive when the broader population in question is listed as vulnerable or threatened ${ }^{6,13}$ and can result in disturbing natural fluctuations in population numbers. ${ }^{28}$ The most humane way to kill an elephant is with a brain shot, but this requires a skilled shooter due to the skull and muscle structure of the head. ${ }^{12,13}$ Entire family units must be culled because of strong family bonds. ${ }^{3,13,15}$ KNP culled elephants from 1967-1994, ${ }^{12,29,30}$ but stopped after receiving pressure from international and animal welfare groups. ${ }^{12}$ Bison can be shot in the field or sent to an abattoir. ${ }^{20}$ Selection for bison culling is determined by desired percentages of age groups. ${ }^{31}$ EINP has used culling since 1929 to control the bison population. ${ }^{32}$ Meat from both elephant and bison culls have been sold or donated to surrounding communities. ${ }^{13,20}$

\section{Discussion and Management Implications}

KNP and EINP originally used a similar strategic approach of focussing on population size when applying population control methods, but KNP has now proposed to use 

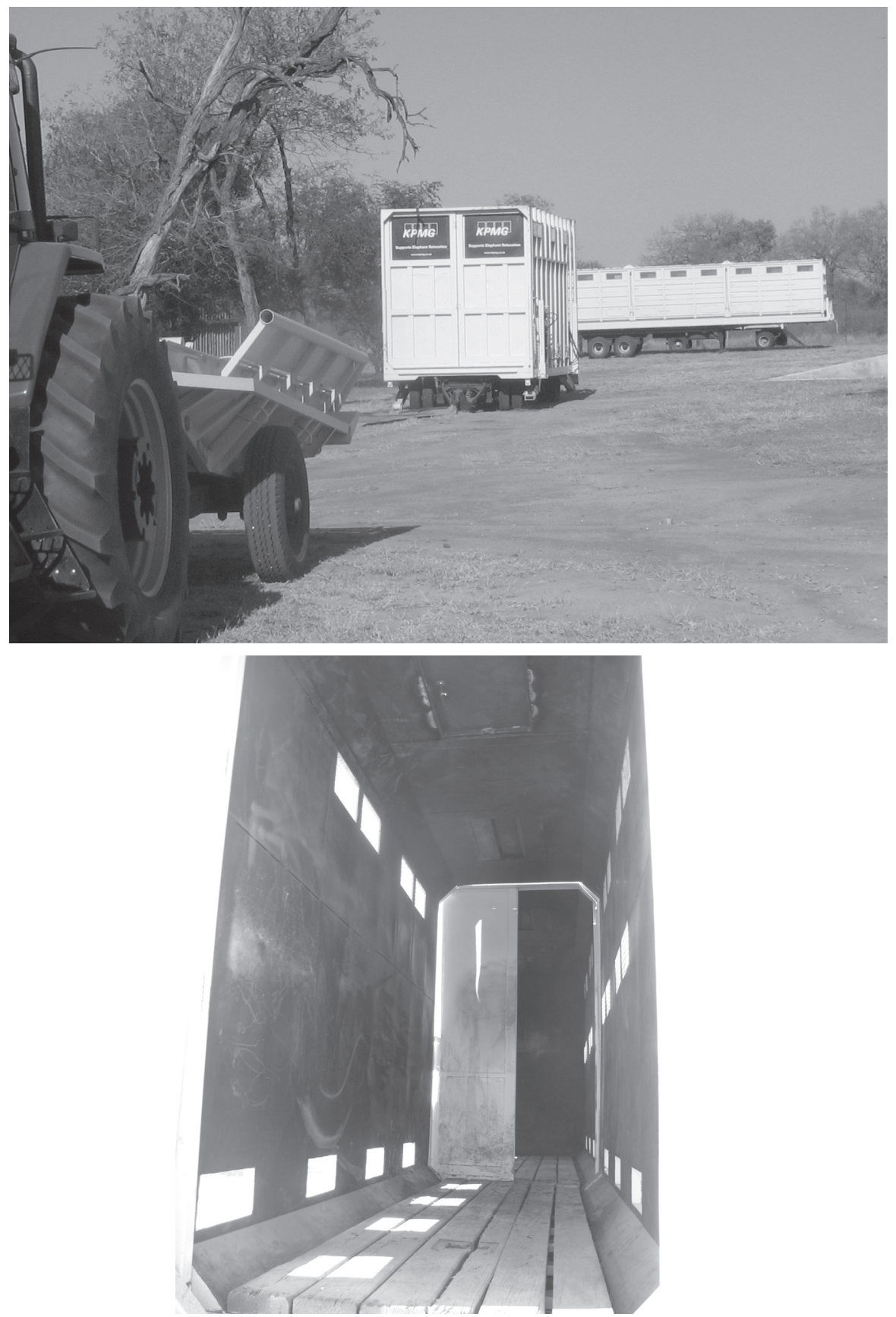

Top: The trailers used to move African elephants during relocation.

Bottom: The inside of an elephant trailer that has two compartments

-Kiva Olson 
a strategy of controlling impacts instead. This strategy proposed by KNP is striving to deal with the root cause of a large elephant population by managing the landscape which the animals use instead of just the effects. All of KNP's proposed plans include zoning with areas of high and low elephant impacts. ${ }^{12,29,30}$ The zones are maintained by contraception and culling along with controlling the distribution, availability, and accessibility of key resources such as water and vegetation. An active adaptive approach backed by research is needed for this to succeed. The opening up of the boarders of KNP to combine its land area with private game reserves and Mozambique's Limpopo National Park does help to spread out the elephant population but does not necessarily address the issue of hyperabundancy. The new area may still not be large enough to sustain a large elephant population and maintain biodiversity. Elephants move to where they can acquire food and water. ${ }^{28}$ Thus, to manage impacts rather than specific population numbers it has been suggested to use fire and water management to guide elephants into the proposed zoned areas for high and low impacts. However, in KNP, cow/calf herd distribution is related to rivers more than artificial watering holes, whereas bulls appear to prefer artificial watering holes. ${ }^{33}$ These distribution trends make it more complicated to control distribution. There are also the effects on other species to consider. The impacts of controlled burns on elephant habitat use are still in their infancy. It can be inferred from vegetation preferences that a freshly burned section would deter elephants because they prefer vegetation that is diverse and complex. ${ }^{28}$ However, this strategy requires an understanding of the impacts of abiotic and biotic factors on the distribution of large herbivores ${ }^{34}$ and how they can be used to mimic natural distribution patterns.

EINP has used the methods of culling and translocation, with variation in implementation. Currently, EINP uses a 'fast-tracking' method of translocation where only those bison leaving the park are processed in corrals. ${ }^{20}$ Historically, with fairly high accuracy of bison numbers, almost all bison in the park were processed every 1-2 years. ${ }^{32}$ EINP can benefit from integrating KNP's proposed impact management into their bison management strategy which could result in a better mimicry of natural processes. There is no water management plan in EINP like there is in KNP because of the different ecosystem. However, EINP has a fire and vegetation management plan that could be incorporated into the bison management plan. Bison have been found to prefer newly burned areas because of the high quality food, even in wooded areas. ${ }^{34}$ Bison will naturally move into more freshly burned areas thereby decreasing their impacts on other areas. The integration of fire management into the bison management plan would assist EINP in forming a management strategy based on impact control rather than specific population numbers. Since 
EINP's management plan currently consists of what KNP has done in the past, there are no fundamental management ideas from EINP that can be integrated into KNP's current elephant management strategies. What KNP needs now is an approved management plan for their elephant population so that they can continue to support their rich biodiversity.

The choice of strategies to manage populations of large herbivores is deeply impacted by public opinions (i.e. social views on culling of elephants have delayed approval of KNP's elephant management plan, even though culling occurs for buffalo and other ungulates). To increase public acceptance, parks staff must provide the public with a rationale for using any strategies for managing large herbivore populations. In addition, animal populations are subject to fluctuations and chance events that can drastically alter population sizes. KNP's proposed elephant management plan appears to be trying to accommodate for these natural changes in elephant populations and use natural distribution factors, while still maintaining biodiversity.

With parks around the world increasingly becoming 'islands' of wilderness, management plans should start addressing impacts relating to population sizes of species since non-management approaches will no longer be effective. A comparison of large herbivore management strategies at KNP and EINP demonstrates how distant parks can learn from each other about ways of managing similar wildlife issues using the same methods but with different strategies guiding the implementation. As well it serves as a case study highlighting the impacts of large herbivores with abundant populations that is relevant to herbivore species of any body size. Such comparisons, resulting from a careful examination of underlying principles and practices, can be beneficial for other parks around the world in developing innovative wildlife management strategies, sometimes using methods they already employ.

\section{Acknowledgements}

We thank S. Ferreira from SANParks and A. Handel from EINP for information about elephant and bison management in their respective parks.

\section{Owen-Smith RN (1988)} Megaherbivores: the influence of very large body size on ecology. Cambridge University Press, New York, New York, USA.

2. Whyte IJ (2001) Headaches and heartaches, the elephant management dilemma. In Schmidtz D, Willot E (eds). Environmental ethics: introductory readings. Oxford University Press, New York, New York, USA. p. 293-305.

3. Whyte IJ, Fayrer-Hosken R (2008) Playing elephant God: ethics of managing wild African elephant populations. In Wemmer C, Christen CA (eds). Elephants and ethics: toward a morality of coexistence. Johns Hopkins University Press, 
Baltimore, Maryland, USA. p. 399417.

4. Campbell C, Campbell ID, Blyth CB, MacAndrews JH (1994) Bison extirpation may have caused aspen expansion in Western Canada. Ecography 17(4):360-362.

5. Kerley G, Landman M, Kruger L, Owen-Smith N (2008) Effects of elephants on ecosystems and biodiversity. In. Scholes RJ, Mennell KG (eds). Elephant management: a scientific assessment for South Africa. Wits University Press, Johannesburg, South Africa. p. 146-205.

6. van Aarde R, Whyte IJ, Pimm S (1999) Culling and the dynamics of the Kruger National Parks African elephant population. Animal Conservation 2:287-294.

7. Terborgh J, Lopez L, Nuñez PV, Rao M, Shahabuddin G, Orihuela G, Riveros M, Ascanio R, Adler GH, Lambert TD, Balbas L (2001) Ecological meltdown in predatorfree forest fragments. Science 294: 1923-1925.

8. IUCN (2012) The IUCN red list of endangered species. http://www. iucnredlist.org/details/12392/0. Accessed 23 July 2012.

9. Polziehn RO, Strobeck C, Beech R, Sheraton J (1996) Genetic relationships among North American bison populations. Canadian Journal of Zoology 74:738-749.

10. Committee on the Status of Endangered Wildlife in Canada
(2012) Wildlife species search. http://www.cosewic.gc.ca/eng/sct1/ index_e.cfm. Accessed 23 July 2012.

11. Parks Canada Agency (2011) Elk Island National Park of Canada management plan. Parks Canada Agency, Ottawa, Ontario, Canada.

12. SANParks (2008) Towards a new elephant management policy for South Africa (1995-2008). South African National Parks, Pretoria, South Africa.

13. Balfour D, Dublin HT, Fennessy J, Gibson D, Niskanen L, Whyte IJ (2007) Review of options for managing the impacts of locally overabundant African elephants. IUCN, Gland, Switzerland.

14. Waithaka J (2008) Policy on management of hyperabundant wildlife populations in Canada's national parks. Proceedings of the 2008 Parks for Tomorrow Conference. Parks Canada, Gatineau, Quebec, Canada.

15. Department of Environmental Affairs and Tourism (2008) National norms and standard for the management of elephants in South Africa. Government of South Africa, Pretoria, South Africa.

16. SANParks (2008) Kruger National Park management plan revised and updated December 2008. South African National Parks, Pretoria, South Africa.

17. Grobler DG, van Altena JJ, Malan JH, Mackey RI (2008) Elephant 
translocation. In Scholes RJ, Mennell KG (eds). Elephant management: a scientific assessment for South Africa. Wits University Press, Johannesburg, South Africa. p. 241-156.

18. Dublin HT, Niskanen LS, editors (2003) Guidelines for the in situ translocation of the African elephant for conservation purposes. IUCN, Gland, Switzerland.

19. Butterfield L (1990) Transporting buffalo. Buffalo 18(3):16-18.

20. Parks Canada Agency (2009) Ungulate options analysis - final report Elk Island National Park of Canada. Parks Canada Agency, Ottawa, Ontario, Canada.

\section{Asa CS (2005) Types of} contraception: the choices. Pages 29-52 in C. S. Asa and I. J. Porter, editors. Wildlife contraception: issues, methods, and applications. John Hopkins University Press, Baltimore, Maryland, USA.

22. Bokhout B, Nabuurs J, de Jong M (2005) Vasectomy of older bulls to manage elephant overpopulation in Africa: a proposal. Pachyderm 39:97-103.

23. Patton ML, Jöchle W, Penfold LM (2005) Contraception in ungulates. In: Asa CS, Porter IJ (eds). Wildlife contraception: issues, methods, and applications. John Hopkins University Press, Baltimore, Maryland, USA. p. 146-167.

24. Kirkpatrick JF, Lyda RO, Frank
KM (2011) Contraceptive vaccines for wildlife: a review. American Journal of Reproductive Immunology 66:40-50.

25. Fayrer-Hosken RA, Grobler D, van Altena JJ, Bertshinger HJ, Kirkpatrick JF (2000) Immunocontraception of African elephants: a humane method to control elephant populations without behavioural side effects. Nature 407:149.

26. Perdok AA, de Boer WF, Stout TAE (2007) Prospects for managing African elephant population growth by immunocontraception: a review. Pachyderm 42:97-107.

27. Kirkpatrick, JF, Turner JW, Liu IKM, Fayrer-Hosken RA, Rutberg AT (1997) Case studies in wildlife immunocontraception: wild and feral equids and white-tailed deer. Reproduction, Fertility and Development 9:105-110.

28. van Aarde $R$, Ferreira $S$, Jackson T, Page B, de Beer Y, Gough K, Guldemond R, Junker J, Olivier P (2008) Elephant Population Biology and Ecology. In Scholes RJ, Mennell KG (eds). Elephant management: a scientific assessment for South Africa. Wits University Press, Johannesburg, South Africa. p. 84-145.

29. Grant R, Sherwill T, Rogers $\mathrm{K}$, Biggs $\mathrm{H}$, Freitag-Ronaldson $\mathrm{S}$, Hofmeyr M, Pienaar D, Joubert $M$ (eds) (2008) An introduction to a new elephant management policy for South African National Parks. SANParks Scientific Service, Pretoria, South Africa. 
30. Whyte IJ, van Aarde R, Pimm S (2003) Kruger's elephant population: its size and consequences for ecosystem heterogeneity. In du Toit JT, Rogers KH, Biggs HC (eds). The Kruger experience: ecology and management of savanna heterogeneity. Island Press, Washington, D.C., USA. p. 332-348.

31. Millspaugh JJ, Gitzen RA, Licht DS, Amelon S, Bonnot TW, Jachowski DS, Jones-Farrand DT, Keller BJ, McGowan CP, Pruett MS, Rittenhouse CD, Suedkamp Wells KM (2008) Effects of culling on bison demographics in Wind Cave National Park, South Dakota. Natural Area Journal 28:240-250.

32. Olson W (date unknown) Bison management in Elk Island National Park. Parks Canada, Fort Saskatchewan, Alberta, Canada.
33. Grant R, Bengis R, Balfour D, Peel M (2008) Controlling the distribution of elephants. In Scholes RJ, Mennell KG (eds). Elephant management: a scientific assessment for South Africa. Wits University Press, Johannesburg, South Africa. p. 329-369.

34. Biondini ME, Steuter AA, Hamilton RG (1999) Bison use of fire-managed remnant prairies. Journal of Range Management 52: 454-461.

35. Estes RD (1999) The safari companion: a guide to watching African mammals. Rev. ed. White river Junction (VT): Chelsea Green Publishing Company. Chapter 21, Elephant Loxodonta africana; p. $223-231$.

36. Olson W (2005) Portraits of the bison: an illustrated guide to bison society. University of Alberta Press, Edmonton, Alberta, Canada.

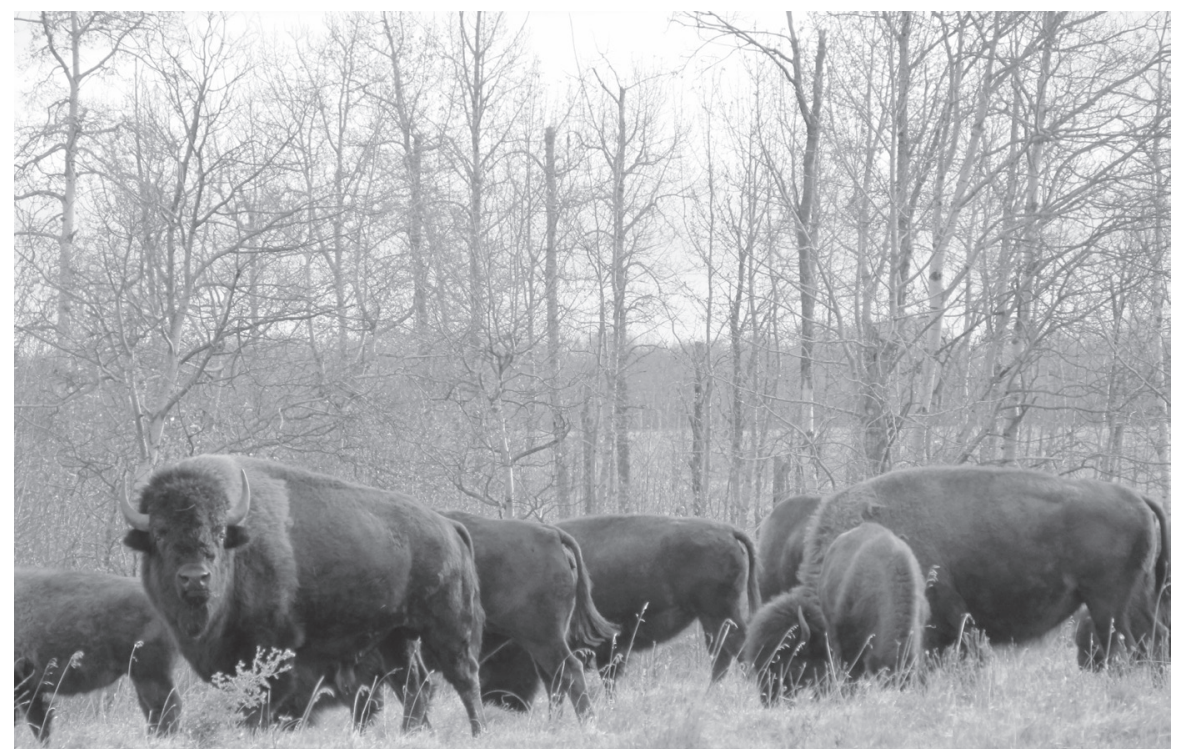

Plains bison herd grazing in Elk Island National Park.

-Kiva Olson 